\title{
Effects of acupuncture in patients with chronic kidney disease: a systematic review
}

\author{
Efeitos da acupuntura em pacientes com insuficiência renal crônica: revisão sistemática \\ Efectos de la acupuntura en pacientes con insuficiencia renal crónica: revisión sistemática
}

Geórgia Alcântara Alencar Melo'
ORCID: 0000-0002-3886-5646

Letícia Lima Aguiar'

ORCID: 0000-0003-0269-1346

Renan Alves Silva"

ORCID: 0000-0002-6354-2785

Francisco Gilberto Fernandes Pereira"'I ORCID: 0000-0002-7744-6030

Fabiana Larissa Barbosa da Silva' ORCID: 0000-0003-1260-1455

Joselany Áfio Caetano' ORCID: 0000-0002-0807-056X

'Universidade Federal do Ceará. Fortaleza, Ceará, Brazil. "Universidade Federal do Espírito Santo. Vitória, Espírito Santo, Brazil. "'Universidade Federal do Piauí. Picos, Piauí, Brazil.

How to cite this article:

Melo GAA, Aguiar LL, Silva RA, Pereira FGF, Silva FLB, Caetano JA. Effects of acupuncture in patients with chronic kidney disease: a systematic review.

Rev Bras Enferm. 2020;73(4):e20180784. doi: http://dx.doi.org/10.1590/0034-7167-2018-0784

Corresponding author:

Geórgia Alcântara Alencar Melo

E-mail: georgiaenf@hotmail.com

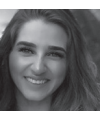

EDITOR IN CHIEF: Antonio José de Almeida Filho ASSOCIATE EDITOR: Italo Rodolfo Silva

Submission: $10-15-2018$

Approval: 07-03-2019

\begin{abstract}
Objectives: to analyze the effects of acupuncture techniques in patients with chronic kidney disease. Methods: a systematic review conducted in six databases, from September to December 2017, following the Preferred Reporting Items for Systematic Reviews and MetaAnalyses' criteria. The following descriptors were used: Acupuncture AND Chronic Renal Insufficiency AND Clinical Trial. Results: nine studies were selected; the acupuncture techniques used were auriculotherapy, electroacupuncture and acupressure aimed at improving quality of life, fatigue, sleep and clinical variables of the disease. The studies that assessed quality of life sleep and fatigue presented significant benefits. Studies that assessed quality of life, sleep and fatigue presented significant benefits. There was no statistical significance in the improvement of serum creatinine levels and glomerular filtration rate. Methodological and assessment tools divergence made impossible meta-analysis Conclusions: studies reinforce the positive effect of acupuncture in improving quality of life, fatigue and sleep in patients.

Descriptors: Acupuncture; Renal Insufficiency, Chronic; Review; Complementary Therapies; Nursing.
\end{abstract}

\section{RESUMO}

Objetivos: analisar os efeitos das técnicas de aplicação da acupuntura em pacientes com insuficiência renal crônica. Métodos: revisão sistemática, conduzida em seis bases de dados, de setembro a dezembro de 2017, seguindo critérios do Preferred Reporting Items for Systematic Reviews and Meta-Analyses. Utilizaram-se descritores: Acupuntura AND Doença Renal Crônica AND Ensaio Clínico, e suas respectivas traduções para o inglês. Resultados: foram selecionados nove estudos, nos quais as técnicas de acupuntura empregadas foram: auriculoterapia, eletroacupuntura e acupressão dos pontos direcionada à melhoria da qualidade de vida, fadiga, sono e variáveis clínicas da doença. Os estudos que avaliaram qualidade de vida, sono e fadiga apresentaram benefícios significativos. Não houve significância estatística na melhora dos níveis de creatinina sérica e taxa de filtração glomerular. A divergência metodológica e dos instrumentos de avaliação impossibilitou a meta-análise. Conclusões: os estudos reforçam efeito o positivo da acupuntura na melhora da qualidade de vida, fadiga e sono em pacientes renais crônicos.

Descritores: Acupuntura; Insuficiência Renal Crônica; Revisão; Terapias Complementares; Enfermagem.

\section{RESUMEN}

Objetivos: analizar los efectos de las técnicas de aplicación de la acupuntura en pacientes con insuficiencia renal crónica. Métodos: revisión sistemática, conducida en seis bases de datos, de septiembre a diciembre de 2017, siguiendo criterios del Preferred Reporting Items for Systematic Reviews and Meta-Analyses. Se utilizaron descriptores: Acupuntura AND Insuficiencia Renal Crónica AND Ensayo Clínico, y sus respectivas traducciones al inglés. Resultados: fueron seleccionados nueve estudios, en los cuales las técnicas de acupuntura empleadas fueron: auriculoterapia, electroacupuntura y acupresión de los puntos dirigida a la mejora de la calidad de vida, fatiga, sueño y variables clínicas de la enfermedad. Los estudios que evaluaron calidad de vida, sueño y fatiga presentaron beneficios significativos. Los estudios que evaluaron la calidad de vida, el sueño y la fatiga presentaron beneficios significativos. No hubo significancia estadística en la mejora de los niveles de creatinina sérica y tasa de filtración glomerular. La divergencia metodológica y de los instrumentos de evaluación imposibilitó el meta-análisis. Conclusiones: los estudios refuerzan el efecto positivo de la acupuntura en la mejora de la calidad de vida, fatiga y sueño en pacientes renales crónicos.

Descriptores: Acupuntura; Insuficiencia Renal Crónica;Revisión;Terapias Complementarias; Enfermería. 


\section{INTRODUCTION}

Acupuncture is a complementary nonpharmacological intervention, with millenarian technique that uses the dualistic cosmic theory, whose balance of yin and yang favors human balance ${ }^{(1)}$. It has been used to control chronic diseases symptoms such as pain, fatigue, nausea, vomiting, depression, anxiety and improvement of quality of life among dialysis patients and other chronic conditions $^{(2-3)}$.

In the context of kidney diseases, Traditional Chinese Medicine explains that the kidneys are responsible for the cycle initial energy and that controls the element Fire (Heart). Therefore, with the development of kidney disease, there is less energy flow available for all other elements, leading to relevant physiological changes. Through acupuncture treatment, it is possible to stimulate points of the Kidney meridian, minimizing the dysfunctions effects generated by these alterations, leading the organism to better functional conditions ${ }^{(4)}$.

The World Health Organization encourages the use of traditional medicines as therapeutics, including Traditional Chinese Medicine (TCM), no longer as a punctual therapeutic resource, but as a complex treatment system. In this context, acupuncture stands out for the satisfactory results in the treatment of several diseases and for the significant cost-benefit, since it is a non-toxic and low-cost therapy ${ }^{(5)}$.

Acupuncture is not limited to the application of needles, having variations according to philosophical basis. Among the techniques used, the following stand out: systemic acupuncture, with the use of needles in specific points throughout the body; electroacupuncture, association of electrical stimulation to needles applied to acupuncture points; laser acupuncture, which applies low intensity laser on acupuncture points, dispensing with needles; acupuncture, using acupuncture needles or crystal beads, mustard, gold or silver at points located in microsystems, such as the skull, atrial (auriculoacupuncture) and hands.

As a way of regulating integrative and complementary practices, in the Brazilian health system, was published Ordinance 971/2006 that regulates the Brazilian National Policy of Integrative and Complementary Practices (PNPIC - Política Nacional de Práticas Integrativas e Complementares). Thus, the inclusion of practices such as TCM/Acupuncture, Homeopathic Medicine, Phytotherapy and Thermalism in the Brazilian Unified Health System (SUS - Sistema Único de Saúde) ${ }^{(6)}$.

In 2018, new Integrative and Complementary Practices (PICS - Práticas Integrativas e Complementares) were incorporated as a modality of care. Currently, SUS has 29 recognized PICS: ayurveda, homeopathy, TCM, anthroposophic medicine, medicinal plants/phytotherapy, art therapy, biodance, circular dance, meditation, music therapy, naturopathy, osteopathy, chiropractic, reflexotherapy, reiki, shantala, integrative community therapy, social therapy/chiropractic, yoga, apitherapy, aromatherapy, bioenergetics, family constellation, chromotherapy, geotherapy, hypnotherapy, hand laying, ozonotherapy and floral therapy ${ }^{(7)}$.

With this incorporation, Brazil becomes the country that leads this offer of modality in Primary Care, with a view to investing in health promotion ${ }^{(7)}$. In this sense, the Federal Nursing Board (COFEN - Conselho Federal de Enfermagem), through Resolution
$326 / 2008$, establishes and recognizes the autonomy of nurses to use acupuncture in professional conducts, as well as the minimum training parameters for nurse qualification ${ }^{(8)}$.

In 2015, COFEN, through Resolution 500/2015, revokes Resolution 197/1997, which establishes and recognizes integrative practices as a specialty and/or qualification of nursing professionals. However, in 2018, it is updated with Resolution 581/2018 and acupuncture is recognized as a nursing specialty. With Resolution $585 / 2018$, nurses are entitled to practice acupuncture ${ }^{(8)}$.

It is worth noting that acupuncture is recognized as a nursing intervention defined by the Classification Intervention of Nursing, which can be performed and directed to modify innumerable human responses, being expressed through the diagnostic concepts: acute pain, chronic pain, impaired physical mobility, risk of electrolyte imbalance, nausea, diarrhea, constipation, anxiety, insomnia, fatigue, activity intolerance, spiritual distress and unbalanced energy field ${ }^{(9)}$.Therefore, acupuncture as a tool/ technology of care for nurses in the search for solutions of human needs faced by individuals in sickness ${ }^{(2,10)}$.

In this context, chronic kidney patients, vulnerable to physical, psychic, social and spiritual changes stand out ${ }^{(1)}$. Therefore, it becomes current and relevant that nurses have the understanding and knowledge of acupuncture as a care technology that is effective in solving these human needs ${ }^{(3-4)}$.

At the present time, there is a timid scientific production in search of evidence that assesses the effects of acupuncture in CKD patients. Therefore, recognizing acupuncture as an effective and effective intervention that optimizes nursing practices in holistic care, based on robust scientific evidence, provides the promotion of health and well-being ${ }^{(11)}$.

Thus, it is necessary to search for evidence of studies on this subject, in order to support acupuncture in CKD patients, as well as to facilitate the choice of techniques, points, length of stay, interval between sessions and indications of therapy.

\section{OBJECTIVES}

To analyze the effects of acupuncture techniques in patients with CKD.

\section{METHODS}

In order to verify the applicability and benefits of acupuncture and its application techniques in CKD patients, a systematic review of the literature ${ }^{(12)}$. This study was guided by the research question elaborated from the PICO strategy, considering "P" (patient) as chronic kidney patients, "I" (intervention) as acupuncture intervention techniques, " $\mathrm{C}$ " (control) as care usual or standard and "O" (outcome) effectiveness of acupuncture. Thus, the guiding question of this review was: what are the effects of acupuncture in the treatment of people with chronic kidney disease?

The study was carried out by the National Library of Medicine, National Institutes of Health (PubMed/MEDLINE), Cochrane Central Register of Controlled Trials (Cochrane Central), Web of Science, Scopus, Cumulative Index to Nursing and Allied Health Literature (CINAHL) databases search, from September to December 2017. 
Controlled descriptors were used, from the Health Sciences Descriptors (DeCs - Descritores em Ciências da Saúde), in order to maximize the search: Acupuncture AND "Chronic Renal Insufficiency"; Acupuncture AND “Chronic Kidney Disease" AND "Clinical Trial”.

Randomized clinical trials with CKD patients, whether dialytic or not, irrespective of gender, ethnicity, or associated comorbidities receiving acupuncture intervention and its variations were established as inclusion criteria. Among them are electroacupuncture, acupressure and auriculotherapy, with techniques derived from the theoretical and philosophical principles of the MTC and the French school from the studies of Paul Nogier, published in English, Portuguese and Spanish; There was exclusion of studies classified with a level of evidence lower than three by the Jadad scores $^{(13)}$ and those performed in a laboratory with animals. No time limit was established for the date of publication of the studies.

In order to guarantee the quality of this step and to avoid selection biases, a search and consensus between two evaluators was carried out for inclusion and exclusion, independently. In the articles that there was disagreement between the two reviewers, we counted with the collaboration of a third reviewer. The selection was composed of two phases: a) screening: assessment of titles and abstracts of all identified studies; b) reading in full: assessment of the full text. The articles were assessed regarding the methodological quality of the randomized clinical trials, based on the Jadad scores ${ }^{(13)}$.

For data extraction of the articles, a tool containing the following information was used: title, author, journal, year, author training, blinding, randomization, country of publication, research objectives, methodological design, tools used for data collection, sample, type of acupuncture intervention techniques, acupoints used and their respective functions according to TCM, length of stay, interval between sessions, main results and conclusions.

The articles were also assessed for methodological quality, selection, randomization, gauging and confounding bias, as well as the losses during follow-up.

\section{RESULTS}

Through the search strategy, 527 studies were identified, with titles and abstracts read. In the first analysis, 465 studies were excluded because they did not fit the inclusion criteria. Thus, the two reviewers independently read the 62 studies in their entirety.

In this stage, 14 articles were selected for further discussion. After critical reading, there was inconsistency between the analyzes, requiring participation of a third evaluator. Thus, there were two studies involving patients after kidney transplantation, in the search performed by the second evaluator. Under consensus, it was decided to exclude these articles, since kidney transplantation is the most effective substitutive therapeutic modality that significantly affects the improvement of clinical parameters and patients' quality of life.

After a group discussion, and in order to guarantee the methodological quality of the review, consensus was established, and the final sample consisted of nine studies that assessed the effects of acupuncture intervention techniques in patients with chronic kidney disease (CKD). The selection process of the articles is illustrated in Figure 1 by the PRISMA's guideline.

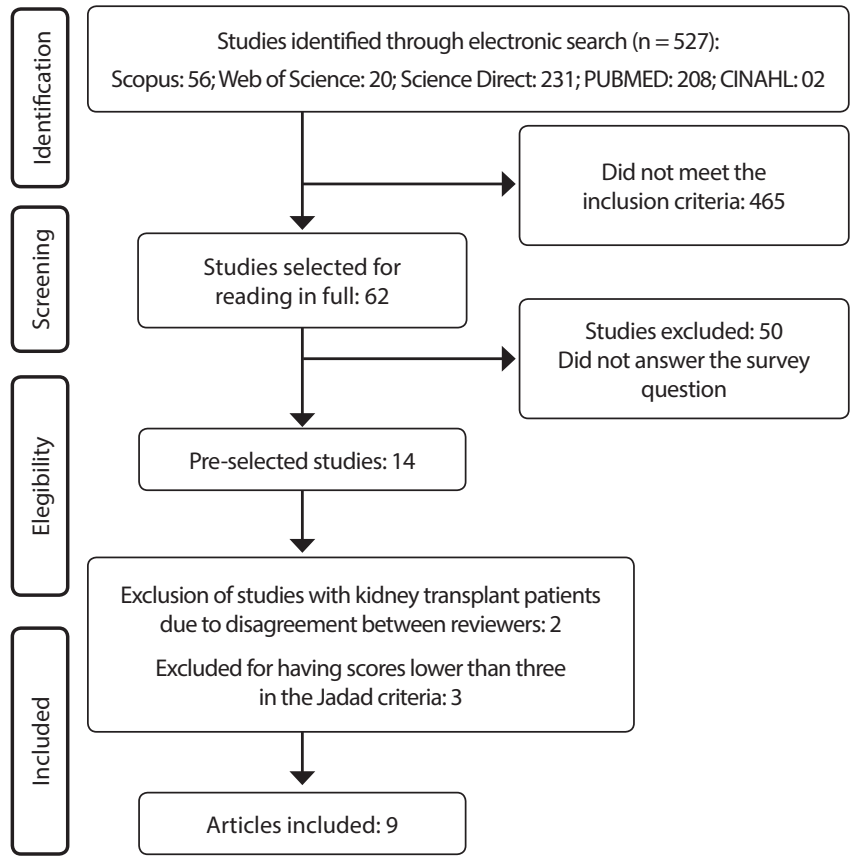

Figure 1-Flowchart of the search process, selection and analysis of review articles, Fortaleza, Ceará, Brazil, 2017

The final sample comprised nine articles, being six from Scopus, two from Pubmed/MEDLINE and one from the Web of Science. To better identify the included studies, Chart 1 presents authors, year, objectives, tools used, methodological quality and subjects of the research.

According to the year of publication, the articles were produced as of 2012, and the latest publications were in 2017. When analyzing professional training, five studies were developed by professional nurses and four by doctors. As for the development site, one article was developed in Australia, two in the United States, one in Taiwan, one in Turkey and four in Iran. Therefore, it is perceived that the theme is discussed as a common problem among the countries, however incipience is observed with regard to publications both in Brazil and in Western countries. The surveys were published in English.

Regarding the tools of data collection, we observed the use of the Medical Outcomes Study 36 - Item Short - Form Health Survey (SF-36) ${ }^{(14)}$; Kidney Disease Quality of Life Short Form (KDQOL-SF) $^{(14)}$; Sociodemographic ${ }^{(15)}$, clinical ${ }^{(15,18,20-21)}$ questionnaire and laboratory tests ${ }^{(15)}$; Brief Fatigue Inventory (BFI) ${ }^{(16)}$; Sleep diary ${ }^{(17)}$; Pittsburgh Sleep Quality Index (PSQI) ${ }^{(17-18,20-21)}$; SF-8 Health Survey ${ }^{(17)}$; Fatigue Severity Scale (FSS) ${ }^{(19)}$; Piper Fatigue Scale (PFS) (19, 22); visual analog scale for fatigue ${ }^{(22)}$.

From the analysis of the objectives of the studies, four assessed the effects of acupuncture on sleep quality; three assessed the effect of acupuncture on fatigue; one assessed the effects of atrial acupuncture on quality of life; and one assessed the effect of acupuncture on kidney function (creatinine and glomerular filtration rate). The studies were performed with a minimum sample size of 42 and a maximum of 118 patients. Chart 2 presents data on clinical outcomes.

As for the acupuncture technique used, two articles $(01,05)$ used atrial acupuncture points (Shenmen, kidney, spleen and heart, Shenmen, sympathetic, subcortex, heart and endocrine). Three (02, 03 and 09) used electroacupuncture, and the others $(04,06,07$ and 08$)$, acupressure. 
Chart 1- Identification of the articles included in the integrative review, Fortaleza, Ceará, Brazil, 2017

\begin{tabular}{|c|c|c|}
\hline $\begin{array}{l}\text { Code, author, } \\
\text { reference } \\
\text { and year }\end{array}$ & Study objectives and research subjects (N) & Methodological Quality \\
\hline $\begin{array}{l}\text { (01) Wang et } \\
\text { al. }{ }^{(14)}, 2014\end{array}$ & $\begin{array}{l}\text { To assess the effectiveness of auricular } \\
\text { acupuncture for improving the quality of life of } \\
\text { diabetic patients with CKD. } \\
\mathrm{N}=62\end{array}$ & $\begin{array}{l}\text { Double-blind, adequately selected and randomized in GE (auriculotherapy) } \\
\text { and GC (routine care). It describes follow-up losses and presents necessary } \\
\text { information on data collection and analysis. }\end{array}$ \\
\hline $\begin{array}{l}\text { (02) Yu et } \\
\text { al. }{ }^{(15)}, 2017\end{array}$ & $\begin{array}{l}\text { To verify the viability effect of acupuncture on } \\
\text { kidney function in patients with CKD. } \\
N=59\end{array}$ & $\begin{array}{l}\text { Blind, adequately selected and randomized DR GE (systemic acupuncture) and } \\
\text { GC (needles inserted outside the acupuncture point). It describes follow-up } \\
\text { losses and presents necessary information on data collection and analysis. }\end{array}$ \\
\hline $\begin{array}{l}\text { (03) Hadadian } \\
\text { et al. }{ }^{(16)}, 2016\end{array}$ & $\begin{array}{l}\text { To analyze the effects of Transcutaneous Electrical } \\
\text { Acupoint Stimulation (TEAS) on CKD fatigue. } \\
\mathrm{N}=56\end{array}$ & $\begin{array}{l}\text { Blind. It does not describe selection and randomization technique. Patients were } \\
\text { divided into GE (TEAS) and GC (TEAS off the acupuncture point). It describes follow- } \\
\text { up losses and presents necessary information on data collection and analysis. }\end{array}$ \\
\hline $\begin{array}{l}(04) \\
\text { Shen et al. }{ }^{(17)} \\
2017\end{array}$ & $\begin{array}{l}\text { To investigate the effect of acupuncture on the } \\
\text { sleep quality of patients underdialysis. } \\
\mathrm{N}=42\end{array}$ & $\begin{array}{l}\text { Double-blind, adequately selected and randomized in GE (systemic acupuncture) } \\
\text { and GC (needles inserted outside the acupuncture point). It describes follow-up } \\
\text { losses and presents necessary information on data collection and analysis. }\end{array}$ \\
\hline $\begin{array}{l}\text { (05) Zou et } \\
\text { al. }^{(18)}, 2015\end{array}$ & $\begin{array}{l}\text { To assess the effects of auriculotherapy in } \\
\text { patients with insomnia. } \\
N=63\end{array}$ & $\begin{array}{l}\text { Double-blind, adequately selected and randomized in GE (auriculotherapy), GC } \\
\text { (routine care). It describes follow-up losses and presents necessary information } \\
\text { on data collection and analysis. }\end{array}$ \\
\hline $\begin{array}{l}\text { (06) Sabouhi } \\
\text { et al. }{ }^{(19)}, 2013\end{array}$ & $\begin{array}{l}\text { To ascertain the effect of acupressure on the } \\
\text { fatigue of patients with CKD. } \\
\mathrm{N}=96\end{array}$ & $\begin{array}{l}\text { Patients appropriately selected. It does not describe technique of randomization } \\
\text { and blinding. Patients were divided into GE (acupressure), Placebo (acupressure } \\
\text { outside the acupuncture point) and GC (routine care). It does not describe follow- } \\
\text { up losses and presents necessary information on data collection and analysis. }\end{array}$ \\
\hline $\begin{array}{l}\text { (07) Arab et } \\
\text { al. }^{(20)}, 2015\end{array}$ & $\begin{array}{l}\text { To investigate the effect of acupuncture on the } \\
\text { sleep quality of patients with CKD. } \\
N=108\end{array}$ & $\begin{array}{l}\text { Blind, appropriately selected and randomized in GE (auriculotherapy), Placebo } \\
\text { (acupuncture auriculotherapy out of the acupoint) and GC (routine care). It does } \\
\text { not describe follow-up losses. Provides necessary information on data collection } \\
\text { and analysis. }\end{array}$ \\
\hline $\begin{array}{l}\text { (08) Shariati et } \\
\text { al. }{ }^{(21)}, 2012\end{array}$ & $\begin{array}{l}\text { To search the effect of acupuncture on the sleep } \\
\text { quality of patients with CKD. } \\
N=48\end{array}$ & $\begin{array}{l}\text { Double-blind, adequately selected and randomized in GE (systemic } \\
\text { acupuncture) and GC (routine care). It describes follow-up losses and presents } \\
\text { necessary information on data collection and analysis. }\end{array}$ \\
\hline $\begin{array}{l}\text { (09) Eğlence } \\
\text { et al. }{ }^{(22),}, 2013\end{array}$ & $\begin{array}{l}\text { To determine the effect of acupuncture on the } \\
\text { level of fatigue in CKD. } \\
N=118\end{array}$ & $\begin{array}{l}\text { Patients adequately selected and randomized. It does not describe blinding } \\
\text { technique. The patients were divided into GE (systemic acupuncture) and GC (routine } \\
\text { care). It describes follow-up losses and presents necessary information on data } \\
\text { collection and analysis. }\end{array}$ \\
\hline
\end{tabular}

Chart 2- Distribution of studies included in the review on clinical outcomes, Fortaleza, Ceará, Brazil, 2017

\begin{tabular}{|c|c|c|}
\hline No & $\begin{array}{l}\text { Type of therapy and time of } \\
\text { intervention }\end{array}$ & Clinical outcomes \\
\hline 01 & $\begin{array}{l}\text { Auriculotherapy once a week/three } \\
\text { months. Shenmen, Kidney, Heart and } \\
\text { Spleen stimulation from three to five } \\
\text { times/day/two minutes. }\end{array}$ & $\begin{array}{l}\text { Patients in the experimental group presented better quality of life ( } 60.2 \text { versus } 76.6, p<0.001) \text {; in the } \\
\text { control group, there was no significant improvement ( } 58.9 \text { and } 61.8, p=0.274) \text {. }\end{array}$ \\
\hline 02 & $\begin{array}{l}\text { Electroacupuncture once a week for } \\
12 \text { weeks, with electrical stimulation } \\
\text { for } 20 \text { minutes in LI4, S36 and K3. }\end{array}$ & $\begin{array}{l}\text { Baseline serum creatinine levels were } 1.45 \mathrm{mg} / \mathrm{dL} \text { in } \mathrm{Gl} \text { and } 1.67 \mathrm{mg} / \mathrm{dL} \text { in } \mathrm{GC}(\mathrm{p}=0.128) \text {. After treatment } \\
\text { with acupuncture, it was } 1.41 \mathrm{mg} / \mathrm{dL} \text { in the Gl; } 1.65 \mathrm{mg} / \mathrm{dL} \text {, in the GC }(p=0.0489) \text {. The baseline GFR } \\
\text { was } 51.85 \mathrm{~mL} / \mathrm{min} / 1.73 \mathrm{~m} 2 \text { in the } \mathrm{Gl} ; 42.50 \mathrm{~mL} / \mathrm{min} / 1.73 \mathrm{~m} 2 \text {, in GC }(p=0.0855) \text {. After treatment with } \\
\text { acupuncture, it was } 54.50 \mathrm{~mL} / \mathrm{min} / 1.73 \mathrm{~m} 2 \text {, in } \mathrm{Gl} ; 43.60 \mathrm{~mL} / \mathrm{min} / 1.73 \mathrm{~m} 2 \text {, in } \mathrm{GC}(p=0.0470) \text {. }\end{array}$ \\
\hline 03 & $\begin{array}{l}\text { Electroacupuncture for five } \\
\text { consecutive weeks, for } 50 \text { seconds. } \\
\text { Ten sessions two to three times a } \\
\text { week in S36, SP6 and LI4. }\end{array}$ & $\begin{array}{l}\text { The mean fatigue score in the } G I \text { and CG groups was } 30.68 \text { and } 26.32 \text {, respectively }(p=0.317) \text {, at the } \\
\text { baseline. Significant differences were found between the IG and } G C \text { groups, } 21.68 \text { and } 35.32 \text {, respectively, } \\
\text { after intervention ( } p=0.002) \text {. When comparing the within groups averages, in } G l \text {, there was a statistically } \\
\text { significant reduction }(p<0.001) \text {, when the two moments were compared, whereas in the CG group, there } \\
\text { was no significant improvement ( }(p=0.731 \text { ). }\end{array}$ \\
\hline 04 & $\begin{array}{l}\text { Acupressure three times a week, } \\
\text { for three minutes, for four weeks } \\
\text { in } H 7, K 11, L 3 \text {. }\end{array}$ & $\begin{array}{l}\text { Both groups demonstrated a reduction in the scores of the Global Sleep Quality Index when compared to } \\
\text { the baseline with the fourth week. However, they were not statistically significant (GI: } 0.52 \text { to } 0.61, p=0.35 \text {, } \\
\text { GC: } 0.74 \text { to } 0.43, p=0.20 \text { ). The differences between GI and GC in the overall PSQI score ( } 0.19 \text { versus } 1.70, \\
p=0.8 \text { ) and on the subscales were small. }\end{array}$ \\
\hline
\end{tabular}




\begin{tabular}{|c|c|c|}
\hline No & $\begin{array}{l}\text { Type of therapy and time of } \\
\text { intervention }\end{array}$ & Clinical outcomes \\
\hline 05 & $\begin{array}{l}\text { Auriculotherapy three to five } \\
\text { times a day for four weeks in } \\
\text { ShenMen, Sympathetic, Subcortex, } \\
\text { Heart, Endocrine. }\end{array}$ & $\begin{array}{l}\text { The overall sleep quality index decreased by } 3.75 \pm 4.36 \text { and } 2.26 \pm 3.89 \text {, after treatment in the IG and CG } \\
\text { groups. The results of analyzes of variance of the measures for the global PSQI score showed a reduction over } \\
\text { time in in the Gl group ( } F=8.47, p<0.01 \text { ) and in the } C G \text { group ( } F=4.09, p<0.01) \text {. Decrease was also found in all } \\
\text { seven domains, except sleep disorders after treatment in the } G \text { l group.After the treatment between two groups } \\
\text { (follow-up) }\left(x^{2}=9.63, p<0.01\right) \text {, there was no significant difference between the two groups }\left(x^{2}=0.77, p=0.38\right) ; \text { and } \\
\text { at the end of follow-up between two groups }\left(x^{2}=4.59, p=0.03\right) \text {. }\end{array}$ \\
\hline 06 & $\begin{array}{l}\text { Acupressure lasting } 20 \text { minutes, } \\
\text { three weekly sessions, for four } \\
\text { weeks in K1, GB34, S36, SP6, } \\
\text { SPL23, H7. }\end{array}$ & $\begin{array}{l}\text { The mean total score and mean fatigue scores in the sensory, behavioral, cognitive and emotional } \\
\text { dimensions in both study groups and placebo were lower after intervention }(p<0.05) \text {. There was a } \\
\text { significant difference in the total variation of the mean fatigue score before and after intervention within } \\
\text { groups (GI: } 6.5 \text { versus } 4.6(p<0.001) \text {, GP: } 6.4 \text { versus } 5.9(p<0.001) \text {, and GC: } 6.4 \text { versus } 6.3(p=0.43) \text { ) and after } \\
\text { intervention between the three groups ANOVA F }=60,012 \text { and } p<0.001 \text {. }\end{array}$ \\
\hline 07 & $\begin{array}{l}\text { Acupressure lasting eight minutes } \\
\text { three times a week for four weeks } \\
\text { in } \mathrm{H7} \text {. }\end{array}$ & $\begin{array}{l}\text { The total score was not different between the groups before the study }(p>0.05, \text { ANOVA). The Pittsburgh } \\
\text { Sleep Quality Score decreased significantly: from } 11.9 \pm 3.13 \text { to } 6.2 \pm 1.93 \text { for } \mathrm{Gl} \text {, from } 11.3 \pm 3.69 \text { to } 10.6 \\
\pm 3.82 \text { in the GP, and from } 10.9 \pm 4.10 \text { to } 10.7 \pm 3.94 \text { in } \mathrm{GC} \text {. There was a significant difference between } \\
\text { groups }(p<0.001) \text {. There was a significant difference between the three groups in the number of nocturnal } \\
\text { awakenings, before and after the study }(p<0.001) \text {. }\end{array}$ \\
\hline 08 & $\begin{array}{l}\text { Acupressure three times a week } \\
\text { for four weeks for } 15 \text { minutes in } \\
\text { H7, LI4 and SP6. }\end{array}$ & $\begin{array}{l}\text { The results showed significant differences in the overall score }(p<0.001) \text { and all sleep quality indices: } \\
\text { subjective sleep quality }(p<0.001) \text {, sleep latency }(p<0.001) \text {, sleep duration }(p<0.001),(p=0.028) \text {, and } \\
\text { diurnal dysfunction }(p<0.001) \text {, when the two groups were compared. }\end{array}$ \\
\hline 09 & $\begin{array}{l}\text { Electroacupuncture three times a } \\
\text { week for four weeks at points S36, } \\
\text { GB34, K1 and SP6. }\end{array}$ & $\begin{array}{l}\text { The mean score on the visual analogue scale for fatigue in EG decreased from } 7.6 \text { at baseline to } 5.0 \text { at } \\
\text { follow-up; while for GC, the mean fatigue score increased from } 6.7 \text { at baseline to } 8.0 \text {, with } p<0.01 \text {. }\end{array}$ \\
\hline
\end{tabular}

The articles mentioned the acupuncture points used for treatment. Five studies highlight the meridian of Kidney (R) (K1, K3, K11 and Kidney in auriculotherapy); six the Heart meridian $(\mathrm{H})$, in which four used the $\mathrm{H} 7$ and two used the heart point in auriculotherapy; four o'clock Stomach (S) 36; four the Spleen-Pancreas (SP) point 6; three point the Large Intestine (LI) 4; and two-point Gallbladder (GB) 34. SPL23 and L3 were also mentioned in a single study. The most commonly used points were S36, SP6 and $\mathrm{H} 7$.

S36, SP6, GB34 and K1 were more used in the studies on fatigue; while $\mathrm{H} 7$ was more commonly used in sleep studies. LI4 was used in studies on sleep, fatigue and clinical conditions.

In relation to the number of acupuncture sessions, eight studies $(01,02,04,05,06,07,08$ and 09) did 12 sessions and one study (03), 10 sessions. There was variation in the time interval between sessions. Two studies (01 and 02) did once a week, while the others, three times a week. Studies 01 and 05 used the auriculotherapy technique and both did 12 sessions. However, study 01 performed the therapy once a week for three months, while the 05 did three times a week for a month.

Regarding studies results, it was observed that the articles that used acupuncture therapy for quality of life and fatigue were successful, with statistically significant improvement within and between groups (01, 03, 06 and 09). However, in a study that assessed serum creatinine and glomerular filtration rate (02), a within group improvement was observed, without statistical significance when compared to the control group.

The studies that verified the use of acupuncture to improve sleep quality differed in the results. Two studies showed significant improvement in within groups and between groups ( 07 and 08), while two studies (04 and 05) had decreased rates when compared to the baseline (within groups), without the difference being statistically significant between the two groups. The four studies were analyzed in isolation, without the calculation of meta-analysis between them.

Among those who did not show significant improvement between groups, one used auriculotherapy (05) and another (04), points H7, K11 and L3. K11 and L3were used only in this study. However, point $\mathrm{H} 7$ was used in another in an isolated way to improve sleep quality (07), with statistical significance, and in both the same acupressure technique was used. Although the studies used the same $\mathrm{H} 7$ point and technique, the acupressure time was different between these. Study 04 performed acupressure for three minutes, while the 07 performed acupressure for eight minutes.

The systemic points used in study 08 to improve sleep quality were similar to those used in article 03 to improve fatigue (LI4 and SP6). Both presented a statistically significant improvement between GE and GC, which can be inferred good results when handling these energy channels.

Three studies assessed improvement of fatigue. One study (03) did 10 sessions (2-3 times a week), while the other two (06 and 09) did 12 sessions ( 3 times a week for a week). 03 used three points (LI4, SP6 and S36), the 06 used six points (K1, GB34, S36, SP6, SPL23 and H7) and the 09 used four points (S36, GB34, K1 and SP6). There was intercession at points S36, SP6, GB34 and $\mathrm{K} 1$ between the studies.

\section{DISCUSSION}

In the Western context, acupuncture has consolidated as a therapeutic resource, in which it must be stimulated the guarantee of the continuity of this use, from the strengthening of the PNPIC, encouraging and encouraging the research. Thus, it is indispensable to insert this technology in all services of Brazilian health care networks, especially in renal therapy services. Thus, 
this intervention, based on holistic principles, when used alone or in combination with other treatment modalities, approaches the patient throughout the health-disease process in acomprehensive and dynamic way ${ }^{(23)}$.

This review points out as therapies that presented good therapeutic response in the management of CKD: auriculotherapy ${ }^{(14,18)}$; acupressure $^{(17-21)}$; and electrical stimulation ${ }^{(15-16,22)}$. It should be emphasized that the techniques used and stimulated points were tested for overall improvement in quality of life ${ }^{(14)}$; reduction of serum creatinine ${ }^{(15)}$; reduction of fatigue $\mathrm{e}^{(16,19,22)}$; and improvement

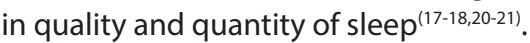

The most used acupressure points in the studies of this review were: $\mathrm{H} 7$ (Shenmen), for improving the quality of sleep and fatigue $^{(14,17-21)} ; \mathrm{LI} 4$, aiming to improve sleep, fatigue and clinical parameters $^{(15-16,21)}$; S36, to improve clinical parameters and fatigue ${ }^{(15-16,19,21)}$; and SP6 that was used to treat fatigue and improve sleep ${ }^{(16,19,21-22)}$.

It is important to consider that the studies included in this review were submitted to the stratification of the quality of scientific evidence, using the Jadad Scale score, considering that all the researches are clinical trials. In this sense, it was detected that all the studies presented high quality of evidence, being four studies $^{(14,17-18,21)}$ with a five and five score ${ }^{(15-16,19-20,22)}$ with a score of three, which were not double-blind between groups.

In this study, it was observed that the systematic review studies were considered of high scientific evidence, through the blinding and randomization procedures, as well as the assessment of selection biases, confounding and data collection information. Other reviews with varying levels of scientific evidence have illustrated the effectiveness of acupuncture in the clinical practice of nurses, such as acupressure at point LI4 during labor to reduce the perception of pain ${ }^{(24)}$; reduction of symptoms such as fatigue, pain, sleep disorders and increased performance in activities of daily living in women with breast cancer ${ }^{(25)}$; and in reduction of typical symptoms of irritable bowel syndrome, through the application of acupuncture and associated moxibustion ${ }^{(26)}$.

As for the effects caused by the use of acupuncture in chronic conditions, research presents results that allow it to be announced as a therapeutic possibility in nursing care, as well as in the acute control of blood pressure, with a mean reduction of $20 \mathrm{mmHg}$ in systolic blood pressure and $15 \mathrm{mmHg}$ in diastolic (27); in obesity treatment, with a reduction in the Body Mass Index (BMI) by $67 \%$ and abdominal circumference in $78 \%{ }^{(28)}$; and in the control of blood glucose levels and lipid metabolism in young women with Diabetes Mellitus ${ }^{(29)}$.

Regarding the applicability of acupuncture as a possible resource in the treatment of CKD and its clinical consequences, it has been demonstrated that it improves the patient's clinical parameters, such as serum and urinary creatinine, cystatin $C$ levels and glomerular filtration rate, through stimulation at points $\mathrm{LI} 4, \mathrm{~S} 36$ and $\mathrm{K} 3^{(30)}$.

It is also argued that acupuncture is capable of generating anti-inflammatory and antihypertensive benefits in people with CKD, mainly by reducing TNF, IL-1 $\beta$, IL- 6 and IL-8 levels, as well as in the increase of IL-10 and of Nitrous Oxide (NO), besides favoring the vascular dilatation ${ }^{(31)}$.

Many patients, when diagnosed with kidney disease and from the insertion of these in the dialysis therapy, undergo several psychological problems. Studies highlight the correlation between chronic kidney disease and the development of psychological illnesses, such as sleep disturbances ${ }^{(32)}$, anxiety and stress ${ }^{(33)}$, which lead to poor quality of life in these patients ${ }^{(34)}$. Thus, it is important to invest in interventional research involving treatments that work the patient holistically.

Specifically regarding sleep disorders, the meta-analysis quantified the effects of non-pharmacological interventions on the improvement of sleep quality in uremic patients on dialysis. It also assessed changes in sleep quality before and after interventions, concluding that acupressure and exercise are promising interventions for improving sleep quality ${ }^{(35)}$. The points worked were H7, LI4 and SP6, added to K11, L3, Heart and Endocrine.

The most used acupressure points in the studies of this review were the $\mathrm{H} 7$ (Shenmen), being used in four studies to improve the quality of sleep and fatigue, which is located in the internal border of pisiform bone. It is considered the door of the spirit, and its function is to calm the mind, with indications to treat insomnia, anxiety, weak memory, nervous palpitation, tachycardia, excitation insomnia, hypertension and urinary incontinence ${ }^{(36)}$.

LI4 was also used in four other studies aimed at improving sleep, fatigue and clinical parameters. It is located on the dorsal side of the hand and is indicated for headache, migraine, generalized muscle tension, anxiety, dysmenorrhea, general pain, chills, cranial neuralgia, insomnia(37-38).

S36 was also used in four studies to improve clinical parameters and fatigue. It is located in the anterolateral portion of the tuberosity of the tibia, serves for disorders of the stomach and has been used in research for cardiovascular outcomes due to the bradycardic and hypotensive effects ${ }^{(39)}$. It is used for the affections of the nervous system, since it deals with energy insufficiency, for people with physical and/or psychic exhaustion ${ }^{(37)}$.

SP6 was used in four studies on fatigue and sleep. It is located behind the medial border of the tibia and is indicated for gynecological, urinary, gastrointestinal, circulatory, pain, palpitation, insomnia, restlessness, tiredness, weakness, appetite reduction, dry skin, and weight control ${ }^{(38)}$. The other points stimulated during the treatment of the cited research are considered positive, from the point of view of providing specific effects that can decrease pain, tone the kidney, calm the mind, benefit the tendons, joints and move energy/blood ${ }^{(39)}$, thus generating health improvements.

Thus, it is verified that acupuncture performed through welldefined and consolidated protocols, derived from empirical experience, when transferred to clinical knowledge, can contribute greatly to the increase of quality of life in patients with CKD. It has also been observed in the studies that the use of the anatomical location of the points will depend on the emotions, affections and feelings that patients experience during the health-disease process $^{(9)}$. Therefore, the individual and comprehensive approach should be considered in the search for relief from conditions experienced by CKD patients ${ }^{(11,40)}$.

However, one should reflect on the real possibility of acupuncture by nephrologist nurses in the Brazilian reality, considering that the training of these professionals is still timid regarding the introduction of complementary integrative practices in the management of CKD ${ }^{(40)}$, as well as the possibilities offered by SUS, regarding the performance of nurses, in care for CKD patients in the various levels of health care, through acupuncture. 


\section{Study limitations}

This systematic review needs to be interpreted with caution because of the included clinical trials and their limitations. In five studies, it was not possible to mask the intervention of participants and professionals, although it is unlikely that there are biases in the results, as evidenced by the analysis of the mean difference tests between and within groups. There was, as a limitation, the number of databases that may have minimized the sample of selected studies to compose the systematic review. It is pointed out that the methodological diversity and data collection tools used in each study made it impossible to perform meta-analysis calculations, and the descriptive analysis may have bias in the results of the review.

\section{Contributions to Nursing, Public Health or Public Policy}

Despite the small scientific production coming from nursing professionals, especially the Latin American ones, the studies point to acupuncture as a possibility for intervention by nursing professionals, in the care of the CKD patient, in order to reduce the negative effects of renal replacement therapy and coexistence with the disease. Therefore, it becomes relevant to stimulate the use of this care technology, as a corpus of knowledge of the issue, thus favoring a humanistic and comprehensive approach in the resolution or minimization of human problems and/or needs. Based on these findings, it should be encouraged that renal replacement therapy services are a propitious space to insert and strengthen integrative and complementary practices, such as acupuncture, in nursing care, through the insertion of acupuncturist nurses.

\section{CONCLUSIONS}

Studies that worked on acupuncture in CKD patients used the techniques of auricular acupuncture, electroacupuncture and acupressure. The proposed treatment was effective in improving quality of life, fatigue and sleep, but did not provoke significant effects on the clinical variables of the disease, such as glomerular filtration rate and serum creatinine. The main acupuncture points were, for quality of life: Shenmen, Kidney and Heart; for clinical conditions: LI4, S36 and K3; for fatigue: S36, SP6, LI4, K1, GB34, SPL23 e H7; and sleep: H7, K11, L3, LI4, SP6, Shenmen, Heart and Endocrine. The intervention time was variable, but there were 12 sessions for one to three times a week.

Further studies with a high level of scientific evidence regarding the effects of acupuncture and their variations, either alone or in combination, are recommended for CKD patients. In addition, it assesses the effects of the main nursing diagnoses related to alterations and loss of kidney function, blood volume and hydroelectrolytic disturbances.

\section{REFERENCES}

1. Arjuna Rao ASM, Phaneendra D, Pavani CD, Soundararajan P, Rani NV, Thennarasu P, et al. Usage of complementary and alternative medicine among patients with chronic kidney disease on maintenance hemodialysis. J Pharm Bioallied Sci [Internet]. 2016 [cited 2017 Sep 25];8(1):52-57. Available from: https://www.ncbi.nlm.nih.gov/pmc/articles/PMC4766780/

2. Romeo MJ, Parton B, Russo RA, Hays LS, Conboy L. Acupuncture to treat the symptoms of patients in a palliative care setting. Explore (NY) [Internet]. 2015 [cited 2017 Sep 25];11:357-362. Available from: https://www.explorejournal.com/article/S1550-8307(15)00108-1/fulltext

3. Hmwe NTT, Subramanian P, Tan LP, Chong WK. The effects of acupressure on depression, anxiety and stress in patients with hemodialysis: a randomized controlled trial. Int J Nurs Stud [Internet]. 2015 [cited 2017 Sep 25];52:509-518. Available from: https://www.ncbi.nlm.nih.gov/ pubmed/25468282

4. Paterno JC, Freire AFO, Teixeira VPC. Acupuntura em Nefrologia: estado da arte. J. Bras. Nefrol [Internet]. 2009 [cited 2017 Sep 12];31(2):167172. Available from: http://bjn.org.br/details/1063/pt-BR/acupuntura-em-nefrologia--estado-da-arte

5. The World Health Organization. WHO traditional medicine strategy 2014-2023 [Internet]. Geneva. 2013 [cited 2017 Nov 5]. Available from: http://www.who.int/medicines/publications/traditional/trm_strategy14_23/en/

6. Ministério da Saúde (MS). Portaria n 971, de 3 de maio de 2006. Aprova a Política Nacional de Práticas Integrativas e Complementares (PNPIC) no Sistema Único de Saúde [Internet]. Diário Oficial da União, Brasília. 2006 [cited 2018 Sep 5] Available from: http://bvsms.saude. gov.br/bvs/publicacoes/politica_nacional_praticas_integrativas_complementares_2ed.pdf

7. Ministério da Saúde (MS). Departamento de Atenção Básica. Mais 10 práticas integrativas são inseridas na PNPIC [Internet]. Brasília. 2018 [cited 2019 Feb 15] Available from: http://dab.saude.gov.br/portaldab/noticias.php?conteudo=_\&cod=2872

8. COFEN. RESOLUÇÃO COFEN No 585/2018. Estabelece e reconhece acupuntura como especialidade e/ou qualificação do profissional de enfermagem [Internet]. Available from: http://www.cofen.gov.br/resolucao-cofen-no-585-2018_64784.html

9. Pereira RDM, Alvim NAT. Acupuncture as a technology for intervention to nursing diagnosis. Rev Enferm UFPE[Internet]. 2016 [cited 2017 Sep 25];10(4):1286-91. Available from: https://periodicos.ufpe.br/revistas/revistaenfermagem/article/view/11115/12590

10. Wagner J. CE: Incorporating Acupressure into Nursing Practice. Am J Nurs[Internet]. 2015[cited 2017 Sep 12];115(12):40-5. Available from: https://insights.ovid.com/pubmed?pmid=26559160

11. Pereira RDM, Alvim NAT. Acupuncture to intervene in nursing diagnosis: assessment of nursing experts. Esc Anna Nery [Internet]. 2016 [cited 2017 Sep 25];20(4):e20160084. Available from: http://www.scielo.br/pdf/ean/v20n4/1414-8145-ean-20-04-20160084.pdf

12. Maglione MA, Maher AR, Ewing B, Colaiaco B, Newberry S, Kandrack R, et al. Efficacy of mindfulness meditation for smoking cessation: A systematic review and meta-analysis. Addict Behav [Internet]. 2017 [cited 2017 Sep 25];69:27-34. Available from: https://www.sciencedirect. com/science/article/abs/pii/S030646031730031X 
Effects of acupuncture in patients with chronic kidney disease: a systematic review Melo GAA, Aguiar LL, Silva RA, Pereira FGF, Silva FLB, Caetano JA.

13. Jadad AR, Moore RA, Carroll D, Jenkinson C, Reynolds DJ, Gavaghan DJ, et al. Assessing the quality of reports of randomized clinical trials: is blinding necessary? Control Clin Trials [Internet]. 1996 [cited 2017 Sep 22];17(1):1-12. Available from: https://www.ncbi.nlm.nih.gov/pubmed/8721797

14. Wang S, Chen Z, Fu P, Zang L, Wang L, Zhai X, et al. Use of Auricular Acupressure to Improve the Quality of Life in Diabetic Patients with Chronic Kidney Diseases: a prospective randomized controlled trial. Evidence-Based Complement Altern Med [Internet]. 2014 [cited 2017 Sep 15];2014:1-11. Available from: https://www.ncbi.nlm.nih.gov/pmc/articles/PMC4276331/

15. Yu JS, Ho CH, Wang HY, Chen YH, Hsieh CL. Acupuncture on renal function in patients with chronic kidney disease: a single-blinded, randomized, preliminary controlled study. J Altern Complement Med [Internet].2017 [cited 2017 Sep 15];23(8):624-631. Available from: http://online.liebertpub.com/doi/10.1089/acm.2016.0119

16. Hadadian F, Sohrabi N, Farokhpayam M, Farokhpayam H, Towhidi F, Fayazi S, et al. The effects of transcutaneous electrical acupoint stimulation (TEAS) on fatigue in haemodialysis patients. J Clin Diagn Res [Internet]. 2016 [cited 2017 Sep 15];10(9):YC01-YC04. Available from: https://www.ncbi.nlm.nih.gov/pmc/articles/PMC5072066/

17. Shen $\mathrm{K}$, Cho Y, Pascoe EM, Hawley CM, Oliver V, Hughes KM, et al. The siestatrial: a randomized study investigating the efficacy, safety, and tolerability of acupressure versus sham therapy for improving sleep quality in patients with end-stage kidney disease on hemodialysis. Evidence-Based Complement Altern Med [Internet]. 2017 [cited 2017 Sep 15];2017:1-10. Available from: https://www.hindawi.com/ journals/ecam/2017/7570352/

18. Zou C, Yang L, Wu Y, Su G, Chen S, Guo X, et al. Auricular acupressure on specific points for hemodialysis patients with insomnia: a pilot randomized controlled trial. PLoS One [Internet]. 2015 [cited 2017 Sep 17];10(4):e0122724. Available from: https://www.ncbi.nlm.nih.gov/pubmed/25874938

19. Sabouhi F, Kalani L, Valiani M, Mortazavi M, Bemanian M. Effect of acupressure on fatigue in patients on hemodialysis. Iran J Nurs Midwifery Res [Internet]. 2013 [cited 2017 Sep 3];18(6):429-34. Available from: http://www.ncbi.nlm.nih.gov/pubmed/24554938

20. Arab Z, Shariati AR, Asayesh H, Vakili MA, Bahrami-Taghanaki H, Azizi H. A sham-controlled trial of acupressure on the quality of sleep and life in haemodialysis patients. BMJ Journals [Internet]. 2015 [cited 2017 Sep 20]; Available from: http://aim.bmj.com/content/ early/2015/07/26/acupmed-2014-010369.full

21. Shariati A, Jahani S, Hooshmand M, Khalili N. The effect of acupressure on sleep quality in hemodialysis patients. Complement Ther Med [Internet]. 2012 [cited 2017 Sep 3];20(6):417-23. Available from: https://www.sciencedirect.com/science/article/pii/ S0965229912001161?via\%3Dihub

22. Eğlence R, Karataş N, Taşci S. The effect of acupressure on the level of fatigue in hemodialysis patients. Altern Ther Health Med. [Internet].2013 [cited 2018Sep 3];19(6):23-31. Available from: https://www.ncbi.nlm.nih.gov/pubmed/24254035

23. Ministério da Saúde (MS). Secretaria de Atenção à Saúde. Departamento de Atenção Básica. Política nacional de práticas integrativas e complementares no SUS: attitude de ampliação do acesso. 2 ed. Brasília: Ministério da Saúde, 2015.

24. Hamlaci Y, Yazici S. The Effect of Acupressure Applied to Point LI4 on Perceived Labor Pains. Holist Nurs Pract[Internet]. 2017 [cited 2018 Sep 3]31(3):167-176.Available from: https://insights.ovid.com/pubmed?pmid=28406870

25. Yeh CH, Chein L-C, Lin W-C, Bovbjerg DH, Van Londen GJ. Pilot Randomized Controlled Trial of Auricular Point Acupressure to Manage Symptom Clusters of Pain, Fatigue, and Disturbed Sleep in Breast Cancer Patients. Cancer Nurs[Internet]. 2016 [cited 2018 Sep 3];39(5):402410.Available from: https://www.ncbi.nlm.nih.gov/pubmed/26390073

26. Anastasi JK, McMahon DJ, Kim GH. Symptom management for irritable bowel syndrome: a pilot randomized controlled trial of acupuncture/ moxibustion. Gastroenterol Nurs [Internet]. 2009 [cited 2018 Sep 3];32(4):243-255. Available from: https://www.ncbi.nlm.nih.gov/ pubmed/19696601

27. Pereira RDM, Alvim NAT, Pereira CD, Gomes Jr SC. Acupuncture in hypertension and your contributions about nursing diagnoses. Esc Anna Nery [Internet]. 2017 [cited 2018 Sep 3];21(1):e20170024. Available from: http://www.redalyc.org/pdf/1277/127749356024.pdf

28. Ornela RG, Oba MVale, Kinouchi FL, Sigoli MA, Scandiuzzi RJ, Soares DW, et al. Acupuntura no tratamento da obesidade. J. Health Sci Inst [Internet]. 2016 [cited 2018 Sep 3];34(1):17-23. Available from: https://www.unip.br/presencial/comunicacao/publicacoes/ics/ edicoes/2016/01_jan-mar/V34_n1_2016_p17a23.pdf

29. WangY, Liu ZC, Xu B. Efficacy analysis on type 2 diabetes mellitus treated with acupuncture in females. Chinese Acupuncture Moxibust[Internet]. 2014 [cited 2018 Sep 3];34(1):21-4.Available from: https://www.ncbi.nlm.nih.gov/pubmed/24673047

30. Dallacosta FM, Dallacosta H, Mitrus L. Detecção precoce de doença renal crônica em população de risco. Cogitare Enferm [Internet]. 2017 [citado 2017 Oct 02];22(2): e48714. Available from: http://revistas.ufpr.br/cogitare/article/view/48714

31. Paterno JC, Freire AFO, Teixeira VPC. Acupuntura em Nefrologia: estado da arte. J Bras Nefrol [Internet]. 2009 [citado 2017 out. 02];31(2):167172. Available from: http://bjn.org.br/details/1063/pt-BR/acupuntura-em-nefrologia--estado-da-arte

32. Sekercioglu N, Curtis B, Murphy S, Barrett B. Sleep quality and its correlates in patients with chronic kidney disease: a cross-sectional design. Ren Fail [Internet]. 2015 [cited 2017 Sep 20];37(5):757-62. Available from: http://www.ncbi.nlm.nih.gov/pubmed/25782921

33. García-Llana H, Remor E, Del Peso G, Selgas R. The role of depression, anxiety, stress and adherence to treatment in dialysis patients' healthrelated quality of life: a systematic review of the literature. Nefrol [Internet]. 2014 [cited 2017 Sep 20];34(5):637-657. Available from: http:// www.ncbi.nlm.nih.gov/pubmed/25259819

34. Theofilou P. Association of insomnia symptoms with kidney disease quality of life reported by patients on maintenance dialysis. Psychol Health Med [Internet]. 2013 [cited 2017 Sep 25];18(1):70-8. Available from: http://www.ncbi.nlm.nih.gov/pubmed/22533530 
35. Yang B, Xu J, Xue Q, Wei T, Xu J, Ye C, et al. Non-pharmacological interventions for improving sleep quality in patients on dialysis: systematic review and meta-analysis. Sleep Med Rev [Internet]. 2015 [cited 2017 Sep 25];23:68-82. Available from: http://www.smrv-journal.com/ article/S1087-0792(14)00129-4/pdf

36. Maciocia G. Os fundamentos da medicina chinesa: um texto abrangente para acupunturistas e fisioterapeutas. São Paulo: Roca, 2007.

37. Cordeiro AT, Cordeiro RC. Acupuntura elementos básicos. 5a ed. São Paulo: Polis; 2014.

38. Lima PR. Manual de acupuntura direto ao ponto. 3a ed. Porto Alegre: Zen; 2016.

39. Xing J, Li J, Zhuang Y, Liang F. Acupuncture Point Specificity. Int Rev Neurobiol [Internet]. 2013 [cited 2017 Sep 25];111:49-65. Available from: https://www.sciencedirect.com/science/article/pii/B9780124115453000031

40. Kim KH, Lee MS, Kim TH, Kang JW, Choi TY, Lee JD. Acupuncture and related interventions for symptoms of chronic kidney disease. Cochrane Database Syst Rev [Internet]. 2016 [cited 2017 Sep 25];(6):CD009440. Available from: https://doi.org/10.1002/14651858.CD009440.pub2 